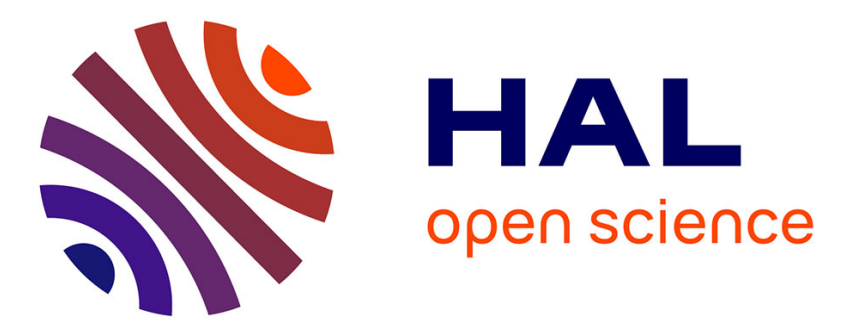

\title{
Direct extraction of oil from sunflower seeds by twin-screw extruder according to an aqueous extraction process: Feasibility study and influence of operating conditions
}

Philippe Evon, Virginie Vandenbossche, Pierre Yves Pontalier, Luc Rigal

\section{To cite this version:}

Philippe Evon, Virginie Vandenbossche, Pierre Yves Pontalier, Luc Rigal. Direct extraction of oil from sunflower seeds by twin-screw extruder according to an aqueous extraction process: Feasibility study and influence of operating conditions. Industrial Crops and Products, 2007, vol. 2 (3), pp. 351-359. 10.1016/j.indcrop.2007.05.001 . hal-00727227

\section{HAL Id: hal-00727227 \\ https://hal.science/hal-00727227}

Submitted on 3 Sep 2012

HAL is a multi-disciplinary open access archive for the deposit and dissemination of scientific research documents, whether they are published or not. The documents may come from teaching and research institutions in France or abroad, or from public or private research centers.
L'archive ouverte pluridisciplinaire $\mathbf{H A L}$, est destinée au dépôt et à la diffusion de documents scientifiques de niveau recherche, publiés ou non, émanant des établissements d'enseignement et de recherche français ou étrangers, des laboratoires publics ou privés. 


\title{
Direct extraction of oil from sunflower seeds by twin-screw extruder according to an aqueous extraction process: Feasibility study and influence of operating conditions
}

\author{
Ph. Evon*, V. Vandenbossche, P.Y. Pontalier, L. Rigal \\ Laboratoire de Chimie Agro-Industrielle, UMR 1010 INRA/INP-ENSIACET, 118 Route de Narbonne, 31077 Toulouse Cedex 4, France
}

\begin{abstract}
The objective of this study was to evaluate the feasibility of an aqueous process to extract sunflower seed oil using a co-rotating twin-screw extruder. Aqueous extraction was carried out using whole seeds and the influence of the operating conditions on oil yield was examined. Operating conditions included screw profile, screw rotation speed, and input flow rates of sunflower seeds and water. Liquid/solid separation required the addition of a lignocellulosic residue upstream from the filtration zone. However, even with maximum fiber input flow, drying of the cake meal did not improve. The lixiviation of the sunflower seeds was also incomplete. The aqueous extraction of the oil was more efficient in the twin-screw extruder than the reference trial conducted in a batch reactor. The best oil extraction yield obtained was approximately 55\% and the residual oil content of the cake meal was approximately $30 \%$. The hydrophobic phases produced were oil-in-water emulsions. These emulsions were stabilized by phospholipids and proteins at the interface, which are natural surface-active agents co-extracted during the process.
\end{abstract}

Keywords: Sunflower; Twin-screw extruder; Aqueous extraction process; Oil and extraction; Proteins and extraction

\section{Introduction}

Sunflower (Helianthus annuus L.) is cultivated for its seeds' high oil content. Oil represents up to $80 \%$ of its economic value. The industrial processes for oil production consist of four successive stages: trituration, pressing, extraction of the residual oil using hexane and refining (Isobe et al., 1992; Rosenthal et al., 1996). The extraction yields are close to $100 \%$ with very good oil quality. However, the use of hexane to remove oil from the oily cake meal is an increasingly controversial

\footnotetext{
* Corresponding author. Tel.: +33 5628857 38; fax: +33562885730.

E-mail address: Philippe.Evon@ensiacet.fr (Ph. Evon).
}

issue and could be prohibited due to its carcinogenicity (Galvin, 1997). Consequently numerous solvents have been considered, including water.

\subsection{Aqueous extraction process}

Several researchers have studied aqueous extraction of oil from various oil-bearing materials such as sunflower (Hagenmaier, 1974; Southwell and Harris, 1992). Water is used since it is immiscible with the oil that is suspended in the water. The fine crushing of the seeds is the first stage in cell disruption. It facilitates the diffusion of the soluble compounds and the release of the oil. Liquid/solid separation by centrifugation produces three fractions: the hydrophobic phase (oil-in-water emulsion), the hydrophilic phase and the insoluble phase 
(Rosenthal et al., 1996; Mechling, 2002). The oil is then recovered after demulsification by alcohol extraction.

Various factors directly influence the efficiency of the aqueous process: size of the solid particles, degree of agitation, $\mathrm{pH}$, temperature, liquid/solid ratio, extraction duration and number of extraction stages. Since the optimal $\mathrm{pH}$ value often coincides with the optimum protein extraction value, aqueous extraction of oil can be regarded as a process primarily aimed at solubilizing proteins which results in the release of the oil (Rosenthal et al., 1996).

Oil bodies are located inside the cell. Oil yield is therefore dependent on how effectively these cells are ruptured during the extraction process. A fraction of the oil remains trapped in the cellular matrix. Most hydrolytic enzymes such as cellulases, hemicellulases and pectinases disrupt the structure of cotyledon cell walls and improve extraction yields (Lanzani et al., 1975; Fullbrook, 1983; Domínguez et al., 1993, 1995; Rosenthal et al., 1996; Sineiro et al., 1998). Proteases can also be used because they degrade both cotyledon cell walls and membranes surrounding lipid bodies, which contain most of the oil in the kernel (Rosenthal et al., 1996). The simultaneous use of hydrolytic and proteolytic enzymes leads in general to better results than an individual enzyme (Lanzani et al., 1975).

\subsection{Twin-screw extrusion}

Extraction efficiency can also be improved by mechanical lysis of the cells in a twin-screw extruder (Isobe et al., 1992; Bouvier and Guyomard, 1997; Lacaze-Dufaure et al., 1999a,b; Amalia Kartika et al., 2005a,b). Co-penetrating and co-rotating twin-screw extruders are most common (Dziezak, 1989). A very wide choice of screw elements is available. The screw elements affect different functions such as conveying, heating, cooling, shearing, crushing, mixing, chemical reaction, liquid/solid extraction, liquid/solid separation, and drying (Rigal, 1996).

The screw profile (or screw configuration) is defined by the arrangement of different characteristics of screw elements (pitch, stagger angle, and length) in different positions and spacings. It is the main factor influencing performance (product transformation, residence time distribution, and mechanical energy input) during extrusion processing (Gogoi et al., 1996; Choudhury et al., 1998; Gautam and Choudhury, 1999a,b).

The forward pitch screws mainly ensure conveying action. The monolobe paddles exert a radial compression and shearing action on the matter but have limited mixing ability. In combination with forward pitch screws, the bilobe paddles exert significant mixing, shearing, conveying, and axial compression actions on the matter. The bilobe paddles are favourable to intimate mixing required in the liquid/solid extraction of soluble constituents in the cell structure. Finally, the reversed pitch screws carry out intensive shearing and considerable mixing on the matter, and exert a strong axial compression in combination with forward pitch screws (Rigal, 1996). The reversed pitch screws are frequently used to place pressure on the matter, which is essential for the separation of liquid and solid phases by filtration.

When oleic sunflower oil is expressed, a longer reversed pitch screw improves oil extraction yield, which can rise $80 \%$ in the optimized operating conditions (Lacaze-Dufaure et al., 1999a). When two reversed pitch screws are used, the oil extraction yield increases with the distance between them and with the decrease of the screw pitch (Amalia Kartika et al., 2005a). The best yield obtained with such screw configuration is close to $70 \%$ but the introduction of a second filtration zone improves it to $85 \%$ (Amalia Kartika et al., 2005a). The corresponding cake meal contains less than $13 \%$ residual oil and the quality of the oil produced is similar to that of classic extraction.

Twin-screw extruders can also be used as liquid/solid extractors. The injection of a solvent promotes oil extraction by solubilizing the triglycerides. A yield of $80 \%$ was obtained with 2-ethylhexanol (Lacaze-Dufaure et al., 1999b) and 85\% with a mixture of sunflower methyl esters (Amalia Kartika, 2005). However, pressing efficiency can be altered by the consistency of the mixture. Liquid/solid separation is more difficult than when the seeds are expressed without injection of a solvent.

This study aimed to show that a co-rotating twinscrew extruder could be used in an aqueous extraction of sunflower oil. It also aimed to show that the extruder's mechanical action efficiently released oil from the seed.

\section{Materials and methods}

\subsection{Materials}

All trials were carried out using a single batch of sunflower seeds (La Toulousaine de Céréales, France). The moisture content of the seeds was $7.49 \pm 0.03 \%$ and the lipid content was $50 \%$ (Table 1). The lipid extract contained $1.2 \mathrm{~g}$ of phospholipids per $100 \mathrm{~g}$ of oil. The three parietal constituents (cellulose, hemicelluloses and lignins) were mainly located in the hulls. The two lignocellulosic residues used were wheat straw and sunflower depithed stalk. Their moisture contents were $6.20 \pm$ $0.02 \%$ and $9.76 \pm 0.05 \%$, respectively. These fibers were 
Table 1

Chemical composition of the sunflower seeds from the batch used for experimental (\% of dry matter)

\begin{tabular}{lrcc}
\hline & \multicolumn{1}{l}{ Seed } & \multicolumn{1}{l}{ Kernel } & \multicolumn{1}{l}{ Hull } \\
\hline Minerals & $3.11 \pm 0.01$ & $2.93 \pm 0.01$ & $2.87 \pm 0.01$ \\
Lipids & $49.70 \pm 0.18$ & $66.60 \pm 0.21$ & $4.80 \pm 0.03$ \\
Phospholipids & $0.59 \pm 0.02$ & - & - \\
Proteins & $15.70 \pm 0.09$ & $18.80 \pm 0.11$ & $4.87 \pm 0.05$ \\
Cellulose & $12.49 \pm 0.20$ & $1.70 \pm 0.04$ & $42.60 \pm 0.23$ \\
Hemicelluloses & $6.88 \pm 0.15$ & $1.47 \pm 0.04$ & $16.10 \pm 0.07$ \\
Lignins & $4.66 \pm 0.10$ & $0.60 \pm 0.02$ & $21.50 \pm 0.12$ \\
\hline
\end{tabular}

previously crushed using a hammer crusher (Electra VS 1, France) fitted with a $6 \mathrm{~mm}$ sieve. All solvents and chemicals were analytical grade and were obtained from Sigma-Aldrich, Fluka, Prolabo and ICS (France).

\subsection{Twin-screw extruder}

Experiments were conducted with a Clextral BC 45 (France) co-penetrating and co-rotating twin-screw extruder. The extruder had seven modular barrels, each $200 \mathrm{~mm}$ in length, and different twin-screws which had segmental screw elements each 50 and $100 \mathrm{~mm}$ in length (Fig. 1). Three modules (modules 3, 4 and 7) were heated to $80^{\circ} \mathrm{C}$ by thermal induction and cooled by water circulation. A filter section consisting of six hemispherical dishes with perforations $1 \mathrm{~mm}$ in diameter was outfitted on module 6 to enable the filtrates containing the extracted oil to be collected. Screw rotation speed $\left(S_{\mathrm{S}}\right)$, the seed feed rate $\left(Q_{\mathrm{S}}\right)$, and the barrel temperature $\left(\theta_{\mathrm{c}}\right)$ were monitored from a control panel.

\subsection{Experimental}

\subsubsection{Aqueous extraction in batch reactor}

Aqueous extraction in batch reactor was carried out using a $1 \mathrm{~L}$ blender (Waring, USA). Crushed sunflower seeds ( $75 \mathrm{~g}$ ) and $425 \mathrm{~g}$ of deionised water ( $\mathrm{pH}$ close to 6.5 and corresponding to the optimal $\mathrm{pH}$ for the oil extraction) were blended for $5 \mathrm{~min}$. The slurry was centrifuged $\left(2000 \times g, 10 \mathrm{~min}, 20^{\circ} \mathrm{C}\right)$ to remove the insoluble phase. The supernatant was then treated by high-pressure homogenisation (300 bar, two cycles) (APV 1000, Denmark) to obtain smaller and more regular oil droplets in the oil-in-water emulsion (Mechling, 2002). The supernatant was centrifuged again $\left(2000 \times g, 10 \mathrm{~min}, 20^{\circ} \mathrm{C}\right)$, to separate the hydrophobic and hydrophilic phases (Mechling, 2002).

\subsubsection{Aqueous extraction in twin-screw extruder}

Whole sunflower seeds were fed into the extruder inlet port by a volumetric screw feeder (Clextral 40, France) located in module 1. Deionised water was injected using a piston pump (Clextral DKM K20-2P32, France) at the start of module 4 (Fig. 1). Two screw profiles (profiles 1 and 2) were tested in this study (Fig. 2). For the two profiles, the seed trituration zone is located in modules 2 and 3. It consists of a succession of 10 monolobe paddles and 5 bilobe paddles, $5 \mathrm{~cm}$ apart. The angle between bilobe paddles was $-45^{\circ}$ (reverse pitch) to prevent the water from going upstream in the extruder. The extraction zone was situated in modules 4 and 5 and was composed of a second series of bilobe paddles. The reversed pitch screws were positioned in module 7 , immediately downstream from the filtration module, to press the liquid/solid mixture. The two screw profiles tested differed only by the type of the reversed pitch screws in the pressing zone (Fig. 2).

The liquid/solid separation was also assisted by the introduction of fibers upstream from the pressing zone. The fibers were fed into the extruder using a volumetric screw feeder (K-Tron Soder KCL-KT20, Switzerland) at the start of module 5 .

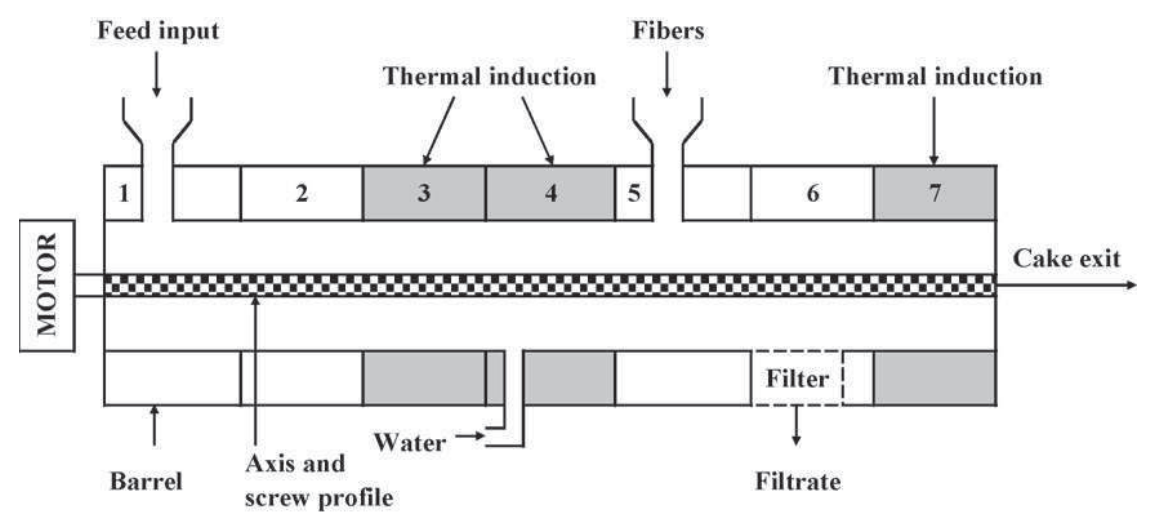

Fig. 1. Schematic modular barrel of the Clextral BC 45 twin-screw extruder used for aqueous extraction of oil from whole sunflower seeds $\left(\theta_{\mathrm{c}}=80^{\circ} \mathrm{C}\right)$. 

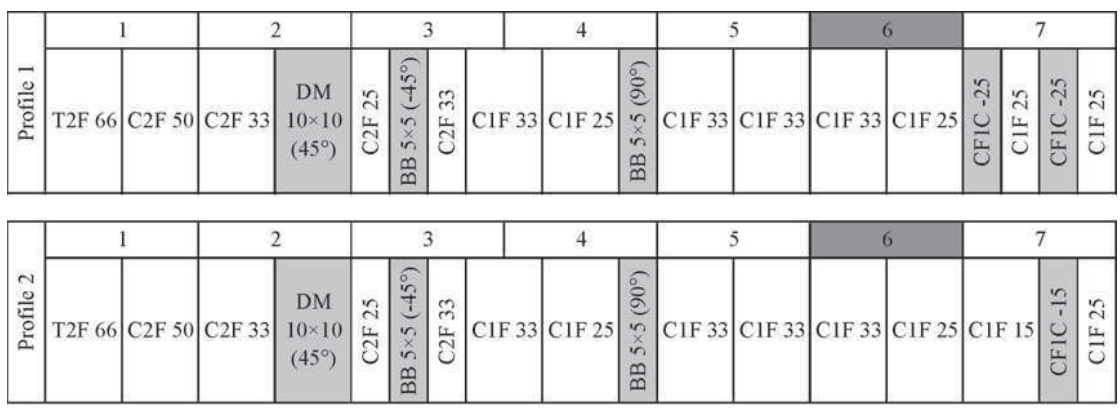

$\mathrm{T} 2 \mathrm{~F}=$ trapezoidal double-thread screw; $\mathrm{C} 2 \mathrm{~F}=$ conveying double-thread screw; $\mathrm{C} 1 \mathrm{~F}=$ conveying simple screw;

$\mathrm{DM}=$ monolobe paddle-screw; $\mathrm{BB}=$ bilobe paddle-screw; $\mathrm{CF} 1 \mathrm{C}=$ reversed screw.

The numbers following the type of the screw indicate the pitch of $\mathrm{T} 2 \mathrm{~F}, \mathrm{C} 2 \mathrm{~F}, \mathrm{C} 1 \mathrm{~F}$ and $\mathrm{CF} 1 \mathrm{C}$ screws and the length

of the DM and BB screws.

Fig. 2. Screw configurations for aqueous extraction of oil from whole sunflower seeds.

The extruder was left to function for 20-25 min before any sampling to ensure the stabilization of the operating conditions. Such conditions include feed flows of seeds and fibers, temperature and current feeding the motor. Upon achieving steady operation, the filtrate (mixture of the hydrophobic phase, the hydrophilic phase and the foot) and the cake meal (insoluble phase) were immediately collected over a period of $20 \mathrm{~min}$ to avoid any variability of the outlet flow rates. Sample collection time was determined with a stopwatch. For each test, sample collection was carried out once. The filtrate and the cake meal were weighed.

The foot, the hydrophobic phase, and the hydrophilic phase were separated as described earlier.

The oil extraction yields were calculated according to the following formulas:

$R_{\mathrm{S}}=\frac{Q_{\mathrm{F}} T_{\mathrm{L}} L_{\mathrm{L}}}{Q_{\mathrm{S}}} \times 100$,

where $R_{\mathrm{S}}$ is the oil yield in proportion to the seed weight $(\%), Q_{\mathrm{S}}$ the inlet flow rate of the whole sunflower seeds $(\mathrm{kg} / \mathrm{h}), Q_{\mathrm{F}}$ the flow rate of the filtrate $(\mathrm{kg} / \mathrm{h}), T_{\mathrm{L}}$ the mass of the hydrophobic phase (light phase) in the filtrate (\%), and $L_{\mathrm{L}}$ is the oil content in the hydrophobic phase of the filtrate $(\%)$.

$R_{\mathrm{L}}=\frac{Q_{\mathrm{F}} T_{\mathrm{L}} L_{\mathrm{L}}}{Q_{\mathrm{S}} L_{\mathrm{S}}} \times 100$

where $R_{\mathrm{L}}$ is the oil yield in proportion to the oil that the seed contains (\%) and $L_{\mathrm{S}}$ is the oil content in the whole sunflower seeds $(\%)$.

$R_{\mathrm{C}}=\frac{\left(Q_{\mathrm{S}} L_{\mathrm{S}}\right)-\left(Q_{\mathrm{C}} L_{\mathrm{C}}\right)}{Q_{\mathrm{S}} L_{\mathrm{S}}} \times 100$, where $R_{\mathrm{C}}$ is the oil yield based on the residual oil content of the cake meal (\%), $Q_{\mathrm{C}}$ the flow rate of the cake meal $(\mathrm{kg} / \mathrm{h})$, and $L_{\mathrm{C}}$ is the oil content in the cake meal (\%).

Although $R_{\mathrm{L}}$ and $R_{\mathrm{C}}$ are expressed in terms of the oil in the seed, $R_{\mathrm{C}}$ is always higher than $R_{\mathrm{L}}$ because it includes all the oil in the filtrate (hydrophobic phase, hydrophilic phase, and foot).

The energy consumed by the motor was determined according to the following formulas:

$P=U I \cos \varphi \frac{S_{\mathrm{S}}}{S_{\max }}$,

where $P$ is the electric power supplied by the motor (W), $U$ the motor's operating voltage $(U=460 \mathrm{~V}), I$ the current feeding the motor (A), $\cos \varphi$ the theoretical yield of the extruder motor $(\cos \varphi=0.95)$, and $S_{\mathrm{S}}$ and $S_{\max }$ are the test speed and maximum speed $(600 \mathrm{rpm})$ of the rotating screws (rpm), respectively.

$\mathrm{SME}=\frac{P}{Q_{\mathrm{S}}+Q_{\mathrm{LCR}}}$,

where SME is the specific mechanical energy consumed by the motor per unit weight of sunflower seeds $(\mathrm{W} \mathrm{h} / \mathrm{kg})$ and $Q_{\mathrm{LCR}}$ is the inlet flow rate of the lignocellulosic residue $(\mathrm{kg} / \mathrm{h})$.

\subsubsection{Analytical methods}

The moisture contents were determined according to the French standard NF V 03-903. The oil content of the solids was determined according to the French standard NF V 03-908. The oil content of the hydrophobic phases was calculated after demulsification of the oil-in-water emulsions using a mix of ethanol and diethyl ether (3/1) (Mechling, 2002). The oil content of the hydrophilic 
phases was calculated by liquid/liquid extraction using a mixture of chloroform and methanol (1/2) according to the method developed by Bligh and Dyer (1959). The phospholipids content of the lipid extracts was calculated according to the French standard NF T 60-227. The protein contents were determined according to the French standard NF V 18-100. An estimation of the three parietal constituents (cellulose, hemicelluloses, and lignins) contained in the solids was made by the ADF-NDF method of Van Soest and Wine $(1967,1968)$. All determinations were carried out in duplicate.

\subsection{Optical microscopy}

Oil droplets in hydrophobic phases were observed with an optical microscope (Nikon Eclipse E 600, Japan). The distribution of the oil droplets size was determined using the Lucia G software (Japan) by manual measurement of the diameter of the 160 droplets on the image. The insoluble phases were observed by optical microscopy after staining with a few drops of Gazet reagent. The average size of the solid particles was evaluated by image analysis (Powdershape, Switzerland).

\section{Results and discussion}

\subsection{Aqueous extraction in batch reactor}

Extraction with a Waring blender was used as a reference process to characterise the aqueous extraction of oil contained in sunflower seeds. Three fractions were obtained from this batch process: a hydrophobic phase, a hydrophilic phase and an insoluble phase (Table 2), as described previously (Rosenthal et al., 1996; Mechling, 2002). The hydrophobic phase was an oil-in-water emulsion that represented $7.5 \%$ of the total mass of the slurry. The water content of this phase was $56 \%$. Lipids represented $84 \%$ of its dry matter, the remainder being composed of proteins, phospholipids, and minerals. The presence of proteins and phospholipids in the hydrophobic phase is indicative of their role as surface-active agents in the emulsion. The surface of the oil droplets appeared to be fine and smooth when observed under the optical microscope. The Gauss-type distribution of the droplets size revealed an average size of the fatty globules of $1.5 \pm 0.4 \mu \mathrm{m}$. The hydrophobic phase was therefore relatively monodisperse, which indicates that oil droplets were not coalescing. This dispersed phase showed good stability over time after high-pressure homogenisation. Nevertheless, the demulsification of the hydrophobic phase was possible using a mixture of ethanol and diethyl ether (3/1) to recover the extracted oil.

The hydrophilic phase (aqueous phase) was the largest phase since the liquid/solid ratio for the extraction was close to 6. It constituted an aqueous extract of the soluble constituents from the seeds. The dry matter content was $2 \%$. Lipids and proteins accounted for $71 \%$ of the dry matter. The presence of a high quantity of lipids indicated that the separation between the hydrophobic phase and the hydrophilic phase was not optimal. The density of the hydrophobic phase was $0.943 \pm 0.001$, which confirmed that separation by centrifugation was possible. However, the recovery of hydrophobic and hydrophilic phases was difficult after centrifugation at laboratory scale, which explained the high percentage of lipids in

Table 2

Proportion and chemical composition of the three fractions obtained after aqueous extraction in a batch reactor and centrifugation

\begin{tabular}{|c|c|c|c|c|}
\hline & Hydrophobic phase & Hydrophilic phase & Insoluble phase & Matter assessment \\
\hline Masses (g) & $37.7(7.5 \%)$ & $307.1(61.4 \%)$ & $155.2(31.0 \%)$ & $500.0(100.0 \%)$ \\
\hline Moisture (\%) & $55.75 \pm 0.45$ & $98.10 \pm 0.01$ & $69.76 \pm 0.07$ & $100.0 \pm 0.1 \%$ \\
\hline \multicolumn{5}{|c|}{ Chemical composition (\% of dry matter) } \\
\hline Minerals & $1.72 \pm 0.18$ & $8.24 \pm 0.22$ & $3.01 \pm 0.01$ & $101.1 \pm 3.1 \%$ \\
\hline Lipids & $83.83 \pm 0.67$ & $39.36 \pm 0.53$ & $39.22 \pm 0.49$ & $100.6 \pm 2.0 \%$ \\
\hline Phospholipids & $0.97 \pm 0.07$ & - & - & - \\
\hline Proteins & $10.85 \pm 0.03$ & $31.78 \pm 0.04$ & $15.03 \pm 0.06$ & $98.4 \pm 1.1 \%$ \\
\hline Cellulose & - & - & $19.02 \pm 0.19$ & - \\
\hline Hemicelluloses & - & - & $10.29 \pm 0.09$ & - \\
\hline Lignins & - & - & $7.10 \pm 0.12$ & - \\
\hline \multicolumn{5}{|c|}{ Extraction yields (\%) } \\
\hline Lipids ${ }^{\mathrm{a}}$ & $40.6 \pm 0.9$ & $6.7 \pm 0.2$ & $46.6 \pm 1.3$ & \\
\hline Proteins ${ }^{b}$ & $16.6 \pm 0.3$ & $17.0 \pm 0.2$ & $35.2 \pm 1.4$ & \\
\hline
\end{tabular}

\footnotetext{
${ }^{a}$ In proportion to the total lipid content of the seed.

${ }^{\mathrm{b}}$ In proportion to the total protein content of the seed.
} 
the aqueous phase. The hydrophilic phase appeared to be incompletely separated from the hydrophobic phase. However, taking into account the low percentage of dry matter, these losses were minimal.

Despite its compact appearance, the insoluble phase obtained after centrifugation was relatively moist. This fraction contained cell debris from the seed breakdown process. It had a porous structure and was largely composed of cellulose. The dry solids contained $39 \%$ lipids, or $53 \%$ of the oil in the seed (Table 2). A reduction of the average size of the solid particles was observed after extraction. The examination of the insoluble phase under the optical microscope showed hull and cell debris as well as numerous intact cotyledon cells. This explains the high percentage of oil remaining in the insoluble phase.

The results showed that the efficiency of the process was limited not only by the penetration of water into the cells but also by the physical destruction (lysis) of the cells.

\subsection{Aqueous extraction in twin-screw extruder}

The twin-screw extruder was used for its capacity to crush the sunflower seeds whilst pressing and mixing. The monolobe paddles and the first series of bilobe paddles reduced the size of the solid particles significantly and released some of the oil. The second series of bilobe paddles extended the mechanical action of seed trituration and promoted the intimate mixing of liquid and solid, thus achieving better contact between the extraction solvent and cells.

The compression action due to the reversed screws was essential to the liquid/solid separation. CF1C screws pushed part of the mixture upstream against the general movement in the extruder. This counter pressure allowed the mixture above the metal filter to be dried and ensured the efficiency of the liquid/solid separation. For good compression to occur, the treated mixture needed to have a high fiber content. As sunflower seeds did not contain sufficient fibers, a lignocellulosic residue had to be introduced upstream from the pressing zone to improve the liquid/solid separation. Wheat straw and sunflower depithed stalk were chosen for their high cellulose and lignin contents and for their low lipid and protein contents (Table 3).

The addition of fibers decreased slightly the protein content of the cake meal. Nevertheless, it would still be suitable for use in animal feeds. New valorisations of the cake meal as a mixture of lignocellulosic fibers and proteins could also be considered. It could be processed into various agromaterials by pressing (Silvestre et al.,
Table 3

Chemical composition of the two tested lignocellulosic residues (\% of dry matter)

\begin{tabular}{lrr}
\hline & Wheat straw & Sunflower depithed stalk \\
\hline Minerals & $7.69 \pm 0.17$ & $4.91 \pm 0.04$ \\
Lipids & $1.44 \pm 0.09$ & $0.91 \pm 0.02$ \\
Proteins & $2.44 \pm 0.02$ & $2.14 \pm 0.09$ \\
Cellulose & $39.72 \pm 0.47$ & $46.13 \pm 0.18$ \\
Hemicelluloses & $31.48 \pm 0.31$ & $18.72 \pm 0.10$ \\
Lignins & $11.51 \pm 0.13$ & $16.90 \pm 0.22$ \\
\hline
\end{tabular}

2000). Panels obtained could be used as inter-layer sheets for pallets for example.

\subsubsection{Influence of operating conditions on oil yield and energy consumption}

Our studies showed that the flow of the lignocellulosic residue must be at least $0.5 \mathrm{~kg} / \mathrm{h}$ for an inlet flow rate of whole sunflower seeds of roughly $15.0 \mathrm{~kg} / \mathrm{h}$, to achieve sufficient liquid/solid separation. An input flow rate higher than $2 \mathrm{~kg} / \mathrm{h}$ of lignocellulosic residue resulted in the clogging of the extruder.

Increasing the input of lignocellulosic residue from 1 to $2 \mathrm{~kg} / \mathrm{h}$ also increased the energy consumption of the extruder motor (Table 4; trials 2 and 3 for the wheat straw, trials 6 and 7 for the sunflower depithed stalk). This tendency was more evident for the sunflower depithed stalk, which is denser and harder due to its higher fiber content. The flow of the lignocellulosic residue only had a limited impact on the oil extraction yield. The lignocellulosic residue acted, above all, like a barrier preventing the liquid from moving forward along the barrel. This helped the filtrate to run through the filtering sieve, even in the case of rather low input of lignocellulosic residue.

The sunflower depithed stalk led to greater energy consumption than the wheat straw for the highest inlet flow rate of lignocellulosic residue (Table 4; trials 2 and 6 then trials 3 and 7). Its use improved the compression of the mixture of water and sunflower seeds in the reversed screws, for an equivalent inlet flow rate. Therefore, the oil yields $\left(R_{\mathrm{C}}\right)$ were higher and the residual oil contents of the cake meal were lower. However, more solid particles were driven through the filter and the filtrate foot content increased slightly with the sunflower depithed stalk. Due to their high lipid contents, it is likely that the feet were composed of kernel residues rather than hull debris (Table 5). The production of the hydrophobic phase was limited with the sunflower depithed stalk, as indicated by the lower oil yields $\left(R_{\mathrm{L}}\right)$ observed. Therefore, the wheat straw was more effective for the required liquid/solid separation. 
Table 4

Results of the aqueous extraction experiments conducted with the Clextral BC 45 twin-screw extruder and using whole sunflower seeds $\left(\theta_{\mathrm{c}}=80^{\circ} \mathrm{C}\right)$

\begin{tabular}{|c|c|c|c|c|c|c|c|}
\hline & \multicolumn{7}{|l|}{ Trial } \\
\hline & 1 & 2 & 3 & 4 & 5 & 6 & 7 \\
\hline \multicolumn{8}{|l|}{ Operating conditions } \\
\hline Screw profile & 1 & 1 & 1 & 1 & 2 & 1 & 1 \\
\hline Fibers type & Wheat straw & Wheat straw & Wheat straw & Wheat straw & Wheat straw & Sunflower depithed stalk & Sunflower depithed stalk \\
\hline$S_{\mathrm{S}}(\mathrm{rpm})$ & 48 & 48 & 48 & 30 & 48 & 47 & 47 \\
\hline$Q_{\mathrm{S}}(\mathrm{kg} / \mathrm{h})$ & 14.0 & 13.9 & 14.0 & 13.1 & 14.7 & 15.1 & 14.8 \\
\hline$Q_{\mathrm{W}}(\mathrm{kg} / \mathrm{h})$ & 19.9 & 36.0 & 34.7 & 36.9 & 35.9 & 35.9 & 35.4 \\
\hline$Q_{\mathrm{LCR}}(\mathrm{kg} / \mathrm{h})$ & 1.0 & 1.0 & 1.8 & 0.9 & 1.0 & 1.2 & 2.0 \\
\hline$C_{\mathrm{F}}(\mathrm{kg} / \mathrm{h} \mathrm{rpm})$ & 0.31 & 0.31 & 0.33 & 0.47 & 0.33 & 0.35 & 0.36 \\
\hline \multicolumn{8}{|l|}{ Filtrate } \\
\hline$Q_{\mathrm{F}}(\mathrm{kg} / \mathrm{h})$ & 16.9 & 34.8 & 32.6 & 32.0 & 34.2 & 34.5 & 34.1 \\
\hline$T_{\mathrm{L}}(\%)$ & 24.3 & 13.6 & 14.3 & 10.4 & 15.8 & 11.7 & 10.4 \\
\hline$T_{\mathrm{H}}(\%)$ & 51.6 & 72.0 & 71.9 & 74.2 & 70.7 & 70.8 & 71.8 \\
\hline$T_{\mathrm{F}}(\%)$ & 24.2 & 14.4 & 13.8 & 15.4 & 13.6 & 17.6 & 17.8 \\
\hline \multicolumn{8}{|l|}{ Moisture (\%) } \\
\hline$H_{\mathrm{L}}$ & $32.47 \pm 0.37$ & $30.15 \pm 0.27$ & $29.27 \pm 0.29$ & $28.79 \pm 0.31$ & $25.83 \pm 0.39$ & $33.47 \pm 0.50$ & $27.73 \pm 0.25$ \\
\hline$H_{\mathrm{H}}$ & $97.16 \pm 0.02$ & $97.35 \pm 0.02$ & $97.00 \pm 0.02$ & $96.97 \pm 0.02$ & $97.34 \pm 0.02$ & $97.33 \pm 0.02$ & $96.87 \pm 0.02$ \\
\hline$H_{\mathrm{F}}$ & $69.37 \pm 0.19$ & $73.88 \pm 0.13$ & $70.86 \pm 0.21$ & $81.52 \pm 0.13$ & $74.13 \pm 0.07$ & $57.97 \pm 0.17$ & $58.82 \pm 0.09$ \\
\hline \multicolumn{8}{|l|}{ Lipids (\% of dry matter) } \\
\hline$L_{\mathrm{L}}$ & $86.76 \pm 0.54$ & $92.48 \pm 0.46$ & $91.63 \pm 0.44$ & $94.34 \pm 0.36$ & $91.81 \pm 0.44$ & $96.43 \pm 0.24$ & $93.94 \pm 0.39$ \\
\hline$L_{\mathrm{F}}$ & $53.46 \pm 0.09$ & $54.15 \pm 0.12$ & $53.55 \pm 0.10$ & $49.57 \pm 0.07$ & $52.98 \pm 0.15$ & $57.11 \pm 0.04$ & $58.96 \pm 0.12$ \\
\hline \multicolumn{8}{|c|}{ Cake meal (insoluble phase) } \\
\hline$Q_{\mathrm{C}}(\mathrm{kg} / \mathrm{h})$ & 18.0 & 16.1 & 17.8 & 19.0 & 17.3 & 17.8 & 18.1 \\
\hline$H_{\mathrm{C}}(\%)$ & $46.60 \pm 0.28$ & $47.45 \pm 0.10$ & $47.91 \pm 0.41$ & $52.57 \pm 0.40$ & $49.89 \pm 0.28$ & $48.33 \pm 0.20$ & $46.69 \pm 0.20$ \\
\hline$L_{\mathrm{C}}(\%$ of dry matter $)$ & $36.00 \pm 0.09$ & $31.84 \pm 0.16$ & $28.99 \pm 0.01$ & $36.82 \pm 0.19$ & $32.79 \pm 0.18$ & $24.00 \pm 0.15$ & $20.19 \pm 0.21$ \\
\hline \multicolumn{8}{|l|}{ Oil extraction yield (\%) } \\
\hline$R_{\mathrm{S}}$ & $17.1 \pm 0.2$ & $21.9 \pm 0.2$ & $21.7 \pm 0.2$ & $16.9 \pm 0.1$ & $25.0 \pm 0.2$ & $17.1 \pm 0.1$ & $16.4 \pm 0.1$ \\
\hline$R_{\mathrm{L}}$ & $37.3 \pm 0.5$ & $47.7 \pm 0.4$ & $47.1 \pm 0.6$ & $36.8 \pm 0.5$ & $54.5 \pm 0.7$ & $37.3 \pm 0.4$ & $35.7 \pm 0.3$ \\
\hline$R_{\mathrm{C}}$ & $46.3 \pm 1.2$ & $57.7 \pm 1.0$ & $58.1 \pm 1.2$ & $45.0 \pm 1.7$ & $57.8 \pm 1.2$ & $68.2 \pm 1.0$ & $71.3 \pm 1.1$ \\
\hline \multicolumn{8}{|l|}{ Energy consumed } \\
\hline$I(\mathrm{~A})$ & 11.0 & 12.0 & 14.0 & 20.0 & 13.0 & 13.5 & 18.5 \\
\hline$P(\mathrm{~W})$ & 384.6 & 419.5 & 489.4 & 437.0 & 454.5 & 462.1 & 633.3 \\
\hline SME (W h/kg) & 25.7 & 28.3 & 31.1 & 31.1 & 28.9 & 28.3 & 37.7 \\
\hline
\end{tabular}

$Q_{\mathrm{W}}$ is the inlet flow rate of the water $(\mathrm{kg} / \mathrm{h}) . C_{\mathrm{F}}$ is the device's filling coefficient $(\mathrm{kg} / \mathrm{h} \mathrm{rpm})$; it is defined as the ratio of the inlet flow rate of the solid matters $\left(Q_{\mathrm{S}}+Q_{\mathrm{LCR}}\right)$ to the screw rotation speed $\left(S_{\mathrm{S}}\right) . T_{\mathrm{H}}$ and $T_{\mathrm{F}}$ are the mass contents of the hydrophilic phase (heavy phase) and the foot in the filtrate (\%), respectively. $H_{\mathrm{L}}, H_{\mathrm{H}}$ and $H_{\mathrm{F}}$ are the moisture contents in the hydrophobic phase, the hydrophilic phase and the foot of the filtrate $(\%)$, respectively. $L_{\mathrm{F}}$ is the oil content in the foot of the filtrate $(\%)$. $H_{\mathrm{C}}$ is the moisture content in the cake meal $(\%)$. 
Table 5

Proportion and chemical composition of the four fractions obtained in trial 3 (profile $1, S_{\mathrm{S}}=48 \mathrm{rpm}, Q_{\mathrm{S}}=14.0 \mathrm{~kg} / \mathrm{h}, Q_{\mathrm{W}}=34.7 \mathrm{~kg} / \mathrm{h}, Q_{\mathrm{LCR}}=1.8 \mathrm{~kg} / \mathrm{h}$ of wheat straw, $\theta_{\mathrm{c}}=80^{\circ} \mathrm{C}$ )

\begin{tabular}{|c|c|c|c|c|c|}
\hline & \multicolumn{3}{|l|}{ Filtrate } & \multirow[t]{2}{*}{ Insoluble phase } & \multirow[t]{2}{*}{ Matter assessment } \\
\hline & Hydrophobic phase & Hydrophilic phase & Foot & & \\
\hline Flows $(\mathrm{kg} / \mathrm{h})$ & $4.7(9.3 \%)$ & $23.5(46.6 \%)$ & $4.5(8.9 \%)$ & $17.8(35.3 \%)$ & $50.5(100.0 \%)$ \\
\hline Moisture (\%) & $29.27 \pm 0.29$ & $97.00 \pm 0.02$ & $70.86 \pm 0.21$ & $47.91 \pm 0.41$ & $100.0 \pm 0.3 \%$ \\
\hline \multicolumn{6}{|c|}{ Chemical composition ( $\%$ of dry matter) } \\
\hline Lipids & $91.63 \pm 0.44$ & $14.29 \pm 0.46$ & $53.55 \pm 0.10$ & $28.99 \pm 0.01$ & $101.1 \pm 1.3 \%$ \\
\hline \multicolumn{6}{|c|}{ Extraction yields (\%) } \\
\hline Lipids $^{\mathrm{a}}$ & $47.1 \pm 0.6$ & $1.6 \pm 0.1$ & $10.9 \pm 0.2$ & $58.1 \pm 0.9$ & \\
\hline Proteins ${ }^{b}$ & $14.6 \pm 0.3$ & $12.5 \pm 0.2$ & $11.8 \pm 0.2$ & $40.4 \pm 1.5$ & \\
\hline
\end{tabular}

a In proportion to the total lipid content of the seed.

b In proportion to the total protein content of the seed.

The increased inlet flow rate of water had a limited effect on energy consumption. It improved oil extraction yields (Table 4; trials 1 and 2) and led to a very clear increase in the hydrophilic phase volume.

A drop in the screw rotation speed increased the device's filling coefficient and the residence time of the solid (Table 4; trials 2 and 4). However, the energy consumed by the motor appeared not to depend on the screw rotation speed since the current feeding the device increased as this speed dropped. Oil yields were lower at $30 \mathrm{rpm}$. It also appeared that the mixture of water and sunflower seeds accumulated more upstream from the reversed screws, masking the filter and therefore preventing the filtrate from flowing freely. A slight decrease in the outlet flow rate of the filtrate and a slight increase in the filtrate's foot content were then observed in this trial. The screw rotation speed of $48 \mathrm{rpm}$ was more efficient.

Profile 2 was constructed using reversed screws with smaller pitch $(-15 \mathrm{~mm}$ instead of $-25 \mathrm{~mm})$ which provided better compression of the mixture in the pressing zone. Thus, the cake meal was dried better (Table 4; trials 2 and 5). The filtrate obtained was richer in hydrophobic phase, resulting in higher oil yields. Furthermore, the reversed screws in profile 2 were further away from the filtration module than in profile 1. As a result, fewer insoluble solids accumulated above the filtering sieve, decreasing the amount of foot in the filtrate.

\subsubsection{Comparison between the Clextral BC 45 twin-screw extruder and the Waring blender mixer}

The twin-screw extruder showed a better aqueous oil extraction than the Waring blender. The best $R_{\mathrm{L}}$ obtained with the twin-screw extrusion technology was approximately 55\% (Table 4; trial 5), 34.5\% higher than what was obtained from the Waring blender. This was achieved with $50 \%$ less water, starting with whole seeds, and shorter extraction times. The drying of the mixture continued to be a difficult stage in the process. Nevertheless, these results showed the potential of the twin-screw extruder when used in aqueous extraction of oil-bearing seeds. The lixiviation of the sunflower seeds was, however, incomplete and the residual oil content of the cake meal was $33 \%$ of dry weight in the best run.

The accuracy of the results obtained for the water, lipid and protein contents of the fractions produced and separated in the twin-screw extruder was confirmed for trial 3 through a matter assessment (Table 5). The dominance of the hydrophilic phase was less significant than for the Waring blender extraction. The hydrophobic phase also had a lipid content noticeably higher and a moisture content lower than that produced in the batch reactor (Tables 2 and 5). The average size of the oil droplets contained in the oil-in-water emulsion was larger than with the Waring blender $(2.9 \pm 1.6 \mu \mathrm{m}$ for trial 3). The stability of this emulsion was satisfactory. After storage for 3 months at $5{ }^{\circ} \mathrm{C}$, only a thin layer of oxidation appeared on the surface but no coalescence process had been activated. The average size of the oil droplets did not change significantly during this time.

\section{Conclusion}

Aqueous extraction of the oil from sunflower seeds was carried out using twin-screw extrusion technology. However, the introduction of a lignocellulosic residue upstream from the filtration module was essential to enable the liquid/solid separation. The process efficiency was limited and the best oil extraction yield was only $54.5 \%$ of the total lipid content of the seed. The residual oil content of the cake meal was approximately 
$30 \%$, partly due to incomplete cell lysis within the seed. Another factor in incomplete oil extraction was the technological limits of the twin-screw extruder that did not enable a full separation of liquid and solid phases. The direct expression in the twin-screw extruder, without solvent injection, was more efficient (oil extraction yield close to $70 \%$ ) than the extraction using water. It would therefore be interesting to conduct the aqueous process after pressing, in the same twin-screw extruder or in two successive apparatus, to improve the overall yield.

During the aqueous extraction process, the oil was extracted in the form of oil-in-water emulsions. After high-pressure homogenisation, the oil droplets had an average size of approximately $3 \mu \mathrm{m}$. Their stability was ensured by the presence at the interface of natural surface-active agents co-extracted during the process, the phospholipids and proteins. Their demulsification by alcoholic extraction made possible to isolate the oil extracted during the process. This process also allowed the production of a protein extract.

\section{References}

Amalia Kartika, I., 2005. Nouveau procédé de fractionnement des graines de tournesol: expression et extraction en extrudeur bi-vis, purification par ultrafiltration de l'huile de tournesol. Thèse de Doctorat. INP, Toulouse, France.

Amalia Kartika, I., Pontalier, P.Y., Rigal, L., 2005a. Oil extraction of oleic sunflower seeds by twin-screw extruder: influence of screw configuration and operating conditions. Ind. Crops Prod. 22, 207-222.

Amalia Kartika, I., Pontalier, P.Y., Rigal, L., 2005b. Extraction of sunflower oil by twin-screw extruder: screw configuration and operating condition effects. Bioresour. Technol. 97, 2302-2310.

Bligh, E.G., Dyer, W.J., 1959. A rapid method of total lipid extraction and purification. Can. J. Biochem. Physiol. 37, 911-917.

Bouvier, J.M., Guyomard, P., 1997. Method and installation for continuous extraction of liquid contained in raw matter. W0974311.

Choudhury, G.S., Gogoi, B.K., Oswalt, A.J., 1998. Twin-screw extrusion of pink salmon muscle and rice flour blends: effects of kneading elements. J. Aquat. Food Prod. Technol. 7, 69-91.

Domínguez, H., Núñez, M.J., Lema, J.M., 1993. Oil extractability from enzymatically treated soybean and sunflower: range of operational variables. Food Chem. 46, 277-284.

Domínguez, H., Núñez, M.J., Lema, J.M., 1995. Aqueous processing of sunflower kernels with enzymatic technology. Food Chem. 53, $427-434$.
Dziezak, J.D., 1989. Single and twin-screw extruders in food processing. Food Technol., 164-174.

Fullbrook, P.D., 1983. The use of enzymes in the processing of oilseeds. J. Am. Oil Chem. Soc. 60, 428-430.

Galvin, J.B., 1997. Toxicity Data for Commercial Hexane and Hexane Isomers. Technology and Solvents for Extracting Oilseeds and Nonpetroleum Oils. AOCS Press, pp. 75-85.

Gautam, A., Choudhury, G.S., 1999a. Screw configuration effect on residence time distribution and mixing in twin-screw extruder during extrusion of rice flour. J. Food Process. Eng. 22, 263-285.

Gautam, A., Choudhury, G.S., 1999b. Screw configuration effect on starch breakdown during twin screw extrusion of rice flour. J. Food Process. Preserv. 23, 355-375.

Gogoi, B.K., Choudhury, G.S., Oswalt, A.J., 1996. Effects of location and spacing of reversed screw and kneading element combination during twin-screw extrusion of starchy and proteinaceous blends. Food Res. Int. 29, 505-512.

Hagenmaier, R.D., 1974. Aqueous processing of full-fat sunflower seeds: yields of oil and protein. J. Am. Oil Chem. Soc. 51, 470-471.

Isobe, S., Zuber, F., Uemura, K., Noguchi, A., 1992. A new twin-screw press design for oil extraction of dehulled sunflower seed. J. Am. Oil Chem. Soc. 69, 884-889.

Lacaze-Dufaure, C., Leyris, J., Rigal, L., Mouloungui, Z., 1999a. A twin-screw extruder for oil extraction. I. Direct expression of oleic sunflower seeds. J. Am. Oil Chem. Soc. 76, 1073-1079.

Lacaze-Dufaure, C., Mouloungui, Z., Rigal, L., 1999b. A twin-screw extruder for oil extraction. II. Alcohol extraction of oleic sunflower seeds. J. Am. Oil Chem. Soc. 76, 1073-1079.

Lanzani, A., Petrini, M.C., Cozzoli, O., Gallavresi, P., Carola, C., Jacini, G., 1975. On the use of enzymes for vegetable-oil extraction. A preliminary report. Riv. Ital. Sostanze Grasse 52, 226-229.

Mechling, E., 2002. Mise au point d'un réacteur multitâches adapté à la production des composés oléophiles à partir des milieux réactionnels issus des graines oléagineuses. Thèse de Doctorat. INP, Toulouse, France.

Rigal, L., 1996. Twin-Screw Extrusion Technology and Fractionation of Vegetable Matter. ENSC, Toulouse, France.

Rosenthal, A., Pyle, D.L., Niranjan, K., 1996. Aqueous and enzymatic processes for edible oil extraction. Enzyme Microb. Technol. 19, 402-420.

Silvestre, F., Gaset, A., Rigal, L., Leyris, J., 2000. Method for making objects from a vegetable raw material by pressing. EP 0,987,089.

Sineiro, J., Domínguez, H., Núñez, M.J., Lema, J.M., 1998. Optimization of the enzymatic treatment during aqueous oil extraction from sunflower seeds. Food Chem. 61, 467-474.

Southwell, K.H., Harris, R.V., 1992. Extraction of oil from oilseeds using the hot water flotation method. Trop. Sci. 32, 251-262.

Van Soest, P.J., Wine, R.H., 1967. Use of detergents in the analysis of fibrious feeds. IV. Determination of plant cell wall constituents. J. Am. Oil Chem. Soc. 50, 50-55.

Van Soest, P.J., Wine, R.H., 1968. Determination of lignin and cellulose in acid detergent fiber with permanganate. J. Am. Oil Chem. Soc. $51,780-784$. 